\title{
ANTIMICROBIAL AND FREE RADICAL SCAVENGING ACTIVITY OF LEAF AND STEM EXTRACT OF LIMONIA ALATA WIGHT AND ARN.
}

\author{
MALATHI S, SEKAR T, SUJATHA S*
}

Department of Botany, Bharathiar University, Coimbatore, Tamil Nadu, India. Email: suja1996bot@gmail.com Received: 13 November 2018, Revised and Accepted: 11 January 2018

\section{ABSTRACT}

Objective: In the present study, antioxidant activities leaves and stem of the petroleum, chloroform, acetone, and methanolic extracts from Limonia alata (L.). Leaf and stem were investigated by employing established in vitro studies. The leaves and bark are used for the fomentation of rheumatic pain; the dried fruit is useful in malignant and pestilent fevers and is used as an antidote for poisons, the folklore claim suggests that the leaf is showing wound healing property. L. alata is belonging to the family Rutaceae.

Methods: The ability of the plant extract to act as hydrogen/electrons donor or scavenger of radicals was determined by in vitro antioxidant assays using 2,2-diphenyl-2-picryl-hydrazyl free radical (DPPH) scavenging, reducing power assay, superoxide radical $\left(\mathrm{O}_{2}{ }^{*-}\right)$ scavenging activity, phosphomolybdenum assay, ferric reducing antioxidant power and metal chelating activity, was performed to know the antioxidant potency and antimicrobial studies of the plant extract of leaves and stem of L. alata.

Result: Results are evaluated higher in leaves, stem and root of L. alata (L.) recorded total phenol (59.95 \pm 5.30$)$. The present state of work was designed to evaluate the phytochemical, antioxidant as well as to screen the antimicrobial present in the plant extracts of $L$. alata. The plant $L$. alata petroleum ether extract of leaf showed greater IC $_{50}$ for DPPH assay $(154.8 \mu \mathrm{g} / \mathrm{mL})$ and compare to another extract, higher reducing power activity stem in methanol (0.99EDTAE/100 g extract), better phosphomolybdenum reduction $(0.512 \mathrm{mg} / \mathrm{g}$ extract) higher ferric reducing power (11542.3 MmolFe(II)E/mg) extract and higher superoxide radical scavenging activity in leaf extract (332.13\%). However, the better metal chelating ability was shown by the water extracts of the leaf (18.24 EDTAE/100 g) compared to other solvent extracts.

Conclusion: The result indicates the antioxidant and antibacterial activity potential of L. alata.

Keywords: Limonia alata, 2,2-diphenyl-2-picryl-hydrazyl free radical assay, Reducing antioxidant power, Antioxidant activity and antimicrobial activity.

(C) 2018 The Authors. Published by Innovare Academic Sciences Pvt Ltd. This is an open access article under the CC BY license (http://creativecommons. org/licenses/by/4. 0/) DOI: http://dx.doi.org/10.22159/ajpcr.2018.v11i4.23643

\section{INTRODUCTION}

Medicinal plants have long been utilized as a source of therapeutic agents worldwide. Higher plants have been used for centuries as remedies for human diseases [1]. Plants are known to produce certain chemicals which are naturally toxic to bacteria [2]. This has encouraged research into a screening of plants for antibacterial and antifungal activities [3]. Free radicals are the character of reactive oxygen species (ROS), which contain all highly reactive, oxygen-containing molecules. Types of ROS contain the hydroxyl radical, the super oxide anion radical, hydrogen peroxide, singlet oxygen, nitric oxide radical, hypochlorite radical, and different lipid epoxides. These free radicals may either be performed by physiological or biochemical method or by pollution and other endogenous cause. All these free radicals are productive of responding with layer lipids, nucleic acids, proteins and chemicals and other little particles, ensuing in cell damage [4]. ROS, sometimes denominated as active oxygen species, are forms of activated oxygen, which include free radicals such as superoxide ions and hydroxyl radicals $(\mathrm{OH})$ [5].

Living organisms have antioxidant defense systems that assure against oxidative damage by replacement or removal of spoiled the molecules [6]. The term "antioxidant" assign to the activeness of numerous vitamins, minerals and phytochemicals which supply strength opposing the damage caused by ROS [7]. A great number of aromatic, medicinal, spice and other plants include chemical compounds express antioxidant character. Oxidative process is one of the most important shows for producing free radicals in foods, drugs and balanced in living systems [8]. The most active path to remove and diminish the action of free radicals which producer the oxidative stress is antioxidative defense technique. Antioxidants are those substances which dominate free radical chain reaction breaking quality. Recently, there has been a promote of benefit in the therapeutic ability medicinal plants as antioxidants in reducing oxidative stress-induced tissue damage [9].

Many plants contain cancer prevention agent mixes, and these mixes secure cells against the harming impacts of receptive oxygen species (ROS, for example, singlet oxygen, superoxide, peroxyl radicals, $\mathrm{OH}$, and peroxynitrite) which brings about oxidative pressure prompting cell harm. Epidemiological examinations have shown the connection between the plant antioxidant and lessening of unending infections [10-12]. Oxidative stress is involved in the pathology of cancer, arteriosclerosis, malaria and rheumatoid arthritis, and could play a role in neurodegenerative diseases and aging processes [15]. Pedilanthus tithymaloides (L.) Poit., belonging to Euphorbiaceae, is an erect shrub originating from tropical America. Indian folklore uses $P$. tithymaloides as antiviral, antibacterial, antihemorrhagic, antitumor, abortive, anticancer, and anti-inflammatory agent [16].

The high cost of natural antioxidants has led to the use of synthetic antioxidants. However, studies conducted subsequently have demonstrated that synthetic antioxidants have toxic effects and, consequently, restrictions have been imposed on their use. Therefore, researchers have focused their studies on plant-derived natural antioxidants [6]. Antioxidant are also defined as a substance which are capable of inhibiting a specific oxidizing enzymes or a substance that reacts with oxidizing agents before causing damage to other molecules 
or a substance that sequesters metal ions or even a substance capable of repairing system such as iron transporting protein [2]. As such, production of free radicals and other ROS in the human body by numerous physiological and bio chemical processes is reported [8].

\section{METHODS}

\section{Plant material}

Theleaf, stem and root parts of L. alata were collected from Maruthamalai tail of Western Ghats, during December 2015. The collected plant material was identified and authenticated by Botanical Survey of India, Southern Circle, Coimbatore (NO.BSI/SRC/5/23/2016/Tech./1180), and the voucher specimen has been deposited in Bharathiar University Herbarium, Department of Botany, and Coimbatore. The collected fresh plant for leaves, stem, and root was cleaned thoroughly with running tap water to remove dust and shade dried for a week at room temperature. The powers were in the airtight container.

\section{Plant extracts preparation}

The powder plant material was extracted as one of the extraction method of Soxhlet extractor based extracted continuously with petroleum ether, chloroform, acetone, and methanol. Each time before extricating with the following dissolvable, the thimble was dried in hot air stove underneath $40^{\circ} \mathrm{C}$. The distinctive dissolvable concentrates were thought by rotating vacuum evaporator and after that air dried. The dried concentrate got with every dissolvable was weighed. The rate yield was communicated as far as air-dried weight of plant material.

\section{Quantification of total phenolics, tannins, and flavonoids Quantification of total phenolics and tannin}

The total phenol content was determined according to the method described by Makkar (2003). $100 \mu \mathrm{L}$ aliquots for plants extracts $(5 \mathrm{mg} / \mathrm{mL})$ were taken in the test tubes and made up to the volume of $1 \mathrm{~mL}$ with distilled water. Then, $500 \mu \mathrm{l}$ of Folin-Ciocalteu reagent (1:1 with water) and $2.5 \mathrm{~mL}$ of sodium carbonate solution $(20 \%)$ were added basically in each tube. Immediately vortexing the reaction mixture, then the test tubes were placed in the dark room for $40 \mathrm{~min}$ and after the absorbance was recorded at $725 \mathrm{~nm}$ against blank. Response blend without plant remove was taken as clear. The examination was performed in triplicate, and the outcomes were communicated as Gallic acid equivalents.

Using the same extract the tannins were estimated after treatment with polyvinyl polypyrrolidone (PVPP) Makkar (2003) 75 mg of PVPP was weighed into a $2 \mathrm{~mL}$ Eppendorf tube and to this $900 \mu \mathrm{L}$ distilled water, and then $750 \mu \mathrm{L}$ of the sample extracts were added. The content was vortexed and kept in the test tube at $4^{\circ} \mathrm{C}$ for $4 \mathrm{~h}$. Then the sample was centrifuged at $4000 \times \mathrm{g}$ for $10 \mathrm{~min}$ at room temperature and the supernatant was collected. This supernatant has just basic phenolics other than the tannins (the tannins would have been encouraged alongside the PVPP). The phenolic substances of the supernatant were measured and show up as the substance of non-tannin phenolics. From the above results, the tannin substance of the example was figured as takes after:

Tannin (in percentage)=Sum of phenolics (in percentage)-Non tannin phenolics (in percentage).

\section{Quantification of total flavonoids}

The flavonoid content of the considerable number of concentrates was evaluated as it goes about as a noteworthy antioxidant in plants diminish es oxidative anxiety. Assessed according to portrayed by Zhishen et al. (1999). Initially, $150 \mu \mathrm{L}$ of all the plant extract were taken in different test tubes. To each extracts $2 \mathrm{~mL}$ of distilled water was added. Then $150 \mu \mathrm{L}$ of $\mathrm{NaNO}_{2}$ was added to all the test tubes followed by incubation at room temperature for $6 \mathrm{~min}$. After incubation $150 \mu \mathrm{L}$ of $\mathrm{AlCl}_{3}(10 \%)$ was added to all the test tubes. The test tubes were incubated for $6 \mathrm{~min}$ at room temperature. Then, $2 \mathrm{~mL}$ of $\mathrm{NaOH}$ was added to all the test tubes which were made up to $5 \mathrm{~mL}$ using distilled water. The contents in all the test tubes were vortexes well and they were allowed to stand for $15 \mathrm{~min}$ at room temperature. The pink color developed due to the appearance of flavonoids was read spectrophotometrically at $510 \mathrm{~nm}$. The amount of flavonoids was calculated as rutin equivalents.

\section{In vitro antioxidant studies}

2,2-diphenyl-2-picryl-hydrazyl free radical (DPPH) radical scavenging activity (Shimade et al., 1992)

The antioxidant movement of the concentrates was resolved regarding hydrogen giving or radical searching capacity, utilizing the steady radical DPPH, as indicated by the strategy for Blois (1958) leaf and stem sample extracts at various concentrations $(20-100 \mu \mathrm{L})$ was added to $5 \mathrm{~mL}$ of $0.1 \mathrm{mM}$ methanolic solution of DPPH and allowed to stand for $20 \mathrm{~min}$ at $27^{\circ} \mathrm{C}$. The absorbance of the sample was measured using the spectrophotometer at $517 \mathrm{~nm}$. Methanol was filled in as blank and arrangement without remove filled in as a control. The mixture of methanol, DPPH and standard (ascorbic acid) filled in as a positive control. Radical scavenging activity was communicated as the restraint percentage of free radical by the sample was figured utilizing the formula. More significantly the $\mathrm{IC}_{50}$ of the extracts were also calculated.

\section{Assay of superoxide radical $\left(\mathrm{O}_{2}{ }^{*-}\right)$ scavenging activity}

The examine was found in the capacity of the example concentrate to check development by searching superoxide radicals begin in riboflavin light nitroblue tetrazolium (NBT) framework (Beauchamp and Fridovich, 1971). Every $3 \mathrm{~mL}$ response blend contained $50 \mathrm{mM}$ sodium phosphate buffer (pH 7.6), $2.33 \mu \mathrm{g}$ riboflavin and $12 \mathrm{mM}$ EDTA, and $11.55 \mathrm{~g}$ NBT. Response was begun by lighting up the response blend with of test extricates (100 $\mu \mathrm{L}$ ) for $90 \mathrm{~s}$. Response blend with extricate kept in dull filled in as a negative control while the blend without separate was taken as clear. Promptly after brightening, the absorbance was measured at $590 \mathrm{~nm}$. The action was contrasted with ascorbic acid. The rate lessening of superoxide anion creation was figured utilizing the accompanying equation:

Level of restraint=(Control OD-Sample OD/Control OD $) \times 100$

\section{Reducing power assay}

The reducing power of different solvent extracts of L. alata was determined by the method reported by Oyaizu, 1986. $500 \mu \mathrm{L}$ of the extract was taken in $2.5 \mathrm{~mL}$ of $0.2 \mathrm{M}$ phosphate buffer $(\mathrm{pH}$ 6.6) was added. To this, $2.5 \mathrm{~mL}$ of $1 \%$ potassium ferricyanide solution was added and the mixture was incubated at $50^{\circ} \mathrm{C}$ for $20 \mathrm{~min}$. After the incubation, $2.5 \mathrm{~mL}$ of $10 \%$ trichloroacetic acid was added. The content was centrifuged at $3000 \mathrm{rpm}$ for $10 \mathrm{~min}$. The upper layer of the supernatant $(2.5 \mathrm{~mL}$ ) was mixed with $2.5 \mathrm{~mL}$ of distilled water and $0.5 \mathrm{~mL}$ of $0.1 \%$ ferric chloride. The absorbance of the reaction mixture was measured spectrophotometer at $700 \mathrm{~nm}$.

Percentage reducing power $=($ Control OD-Sample OD/Control OD $) \times 100$

\section{Phosphomolybdenum assay}

The antioxidant capacity of the extracts has been determine with the phosphomolybdenum reduction assay present to Prieto et al. (1999). The assay was based on the reduction of the extract and subsequent formation of a complex (green color). $0.5 \mathrm{~mL}$ of extract combined with

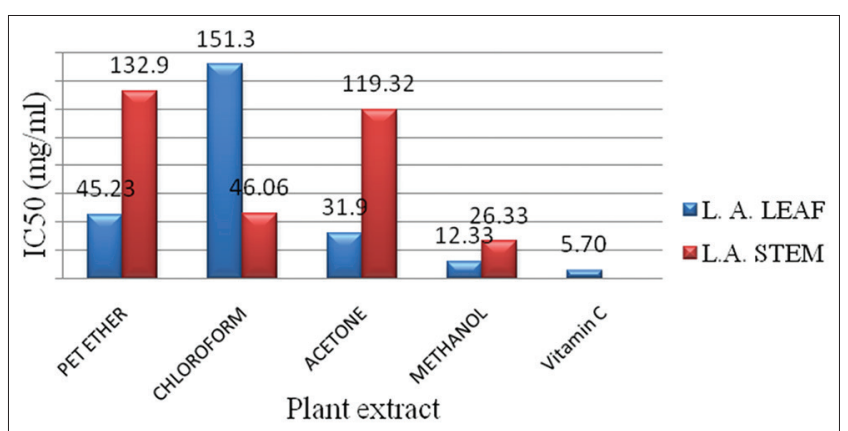

Fig. 1: DPPH scavenging activity of $L$. alata leaf and stem extract 
$3 \mathrm{~mL}$ of reagent solution ( $0.6 \mathrm{M}$ sulfuric acid, $28 \mathrm{mM}$ sodium phosphate, and $4 \mathrm{mM}$ ammonium molybdate) was incubated at $95^{\circ} \mathrm{C}$ for $90 \mathrm{~min}$. The absorbance was taken at $695 \mathrm{~nm}$ using a spectrophotometer. The results were calculated in ascorbic acid equivalents.

Percentage of phosphomolybdenum $=$ (Control OD-Sample OD/Control OD) $\times 100$.

\section{Metal chelating activity}

Principle

Iron II chelating activity was calculated by the check of the creation of Iron(II)-ferrozine complex following preincubation of the sample. The $\mathrm{Fe}^{+}$was monitored by measuring the formation of ferrous iron-ferrozine complex against methanol blank at $562 \mathrm{~nm}$. The chelating of ferrous ions by various extracts in the plant was estimated by the method of (Dinis et al., 1994). The chelating of ferrous ions by various extracts of $L$. alata was estimated. Initially, about $100 \mu \mathrm{l}$ the extract sample was added to $50 \mu \mathrm{l}$ of $2 \mathrm{mM} \mathrm{Fecl}_{2}$ solution. Then the reaction was initiated by the addition of $200 \mu \mathrm{l}$ of $5 \mathrm{mM}$ ferrozine and the test tubes were vortexed well and left standing at room temperature for $10 \mathrm{~min}$. The reaction mixture containing deionized water in place of sample was considered as the negative control absorbance of the solution was then measured spectrophotometrically at $562 \mathrm{~nm}$ against the blank (deionized water). EDTA was against the standard metal chelating specialist, and the outcomes were communicated as mg EDTA counterparts/g extricate chelate the ferrous particle was computed by:

\section{Rate chelation $=(1-[$ ABS test $/ \mathrm{ABS}$ control $]) \times 100$}

\section{Ferric reducing antioxidant power (FRAP)}

The antioxidant contents of phenolic extracts of samples were consideration according to the procedure explained by Pulido et al. (2000). FRAP reagent $(2.7 \mathrm{~mL})$, made freshly and incubated at $37^{\circ} \mathrm{C}$, it was mixed with $270 \mu \mathrm{L}$ of distilled water and $50 \mu \mathrm{L}$ of extract or methanol (for the reagent blank). The test sample and reagent clear were brooded at $37^{\circ} \mathrm{C}$ for $30 \mathrm{~min}$ in a water shower. The last weakening of the test in the response blend was $1 / 34$. The FRAP reagent making $2.5 \mathrm{~mL}$ of $20 \mathrm{mM} / \mathrm{L}$ TPTZ (2,4,6-tripyridyl-s-triazsine) arrangement in $40 \mathrm{mM} / \mathrm{L} \mathrm{HCl}$ in addition to $2.5 \mathrm{~mL}$ of $20 \mathrm{mM} / \mathrm{L} \mathrm{FeCl} 3 \cdot 6 \mathrm{H} 20$ and $25 \mathrm{~mL}$ of $0.3 \mathrm{~m} / \mathrm{L}$ acetic acid derivation support (pH 3.6) clarified by Siddhuraju and Becker, (2003). Toward the finish of hatching, the absorbance readings were taken quickly at $593 \mathrm{~nm}$. Results were ascertained in ferrous sulfate counterparts.

\section{Anti-bacterial activity}

The microbiological assay of the ethanol extract of L. alata leaf was done by comparing the inhibition of the growth by measured concentration of the antibiotics. The bacterial strains used were responsible for producing skin diseases and diarrhea to humans. The bacterial strains used were Streptococcus aureus, and Escherichia coli, and then the fungal culture of Candida albicans, and Fusarium oxysporum were obtained from T. STANES and Company, Phyto-pharma testing lab. All these cultures were maintained on nutrient agar plates at $4^{\circ} \mathrm{C}$, respectively in lab.

\section{Anti-bacterial activity}

Preparation and standardization of inoculums

All the bacterial cultures were transferred into $25 \mathrm{~mL}$ of nutrient broth. The inoculated broths were incubated at $37^{\circ} \mathrm{C}$ for $24 \mathrm{~h}$ (Table 1).

Nutrient agar medium was prepared and transferred into sterile Petri plates. $25 \mathrm{~mL}$ of the standardized bacterial inoculums was spread on agar medium using a sterile cotton swab. The $40 \mu \mathrm{L}$ extracts were added to the well on the agar medium. Amikacin $\left(\mathrm{Ak}^{10}\right)(10 \mu \mathrm{g} / \mathrm{disc})$ was used as a control to determine the sensitivity of each microbial species. All the Petri plates were incubated at $37^{\circ} \mathrm{C}$ for $24 \mathrm{~h}$. After the hatching time frame, the distance across of zone of restraint was measured.

\section{Anti-fungal activity}

Potato dextrose medium was making and transferred into theincubated Petri dish. $200 \mu$ of the standardized fungal inoculum was spread on agar medium using a sterile cotton swab. The $40 \mu \mathrm{L}$ extracts were added to the well on the agar medium. Amikacin $\left(\mathrm{Ak}^{10}\right)(10 \mu \mathrm{g} / \mathrm{disc})$ was used as reference standard to determine the sensitivity of each microbial species tested. All the Petri plates were incubated at $27^{\circ} \mathrm{C}$ for $72 \mathrm{~h}$. After the incubation period, the diameter of the zone of inhibition was measured (Table 2).

$\mathrm{C}(\mathrm{sa})=$ concentration of compound in sample

$\mathrm{C}(\mathrm{st})=$ concentration of standard

$A(\mathrm{sa})=$ area of peak in sample

$A(s t)=$ area of peak in standard.

\section{Statistical analysis}

All analyses were performed carried out in triplicates. The results of scavenger activity and total phenolic and total flavonoids contents were performed from the averages of all samples reading mean \pm standard deviation used Excel 2003.

\section{RESULTS AND DISCUSSION}

\section{Quantification of total phenolics, flavonoid and tannin}

The results of total phenolics and tannin contents are showed in Table 3. When obtained for methanol extract of L. alata leaves revealed highest phenolic in the methanolic extract $(33.87 \mathrm{~g} / 100)$ and stem in tannin chloroform $(2.65 \mathrm{~g} / 100 \mathrm{~g})$ extract respectively. Then, the stem of $L$. alata revealed highest phenolic in methanolic $(33.03 \mathrm{~g} / 100 \mathrm{~g})$ and tannin in chloroform $(2.26 / 100 \mathrm{~g})$ extract. The results of flavonoid content are presented in Table 3. In this estimation, in the methanol extract of $L$. alata stem revealed maximum amount of flavonoid content $(38.6 \mathrm{~g} / 100 \mathrm{~g})$ followed by methanol extract of the leaf $(38.6 \pm 2.03 / \mathrm{g})$.

\section{Antioxidant activity}

\section{Radical scavenging activity using DPPH method}

In L. alata leaf extract in chloroform extract shows $(154.8 \mu \mathrm{g} / \mathrm{mL})$ the

higher inhibitory activity whereas methanol shows the minimum $(12.33 \mu \mathrm{g} / \mathrm{mL})$ inhibitory activity. In stem petroleum ether extract shows $(132.9 \mu \mathrm{g} / \mathrm{mL})$ the higher inhibitory activity whereas methanol shows $(26.33 \mu \mathrm{g} / \mathrm{mL})$ the minimum inhibitory activity. The inhibitory percentage of standard natural antioxidant-rutin and synthetic antioxidant-butylated hydroxytoluene was found to be much better than that of plant extracts. Since the DPPH assay can accommodate many samples in a short period and sensitive enough to detect active ingredient at low concentration, the DPPH radical has been widely used to test the capability of mixture as free radical scavengers or hydrogen donors to evaluate the antioxidant activity of the plant extracts and foods (Soares et al., 1997).

\section{Phosphomolybdenum assay}

Phosphomolybdenum assay is successfully used to determine the ability of extracts to reduce Mo (VI) to Mo (V) and subsequent formation of

Table 1: Composition of nutrient agar medium for bacterial culture

\begin{tabular}{lll}
\hline S. No & Composition & Quantity \\
\hline 1 & Peptone $(\mathrm{g})$ & 5 \\
2 & Beef extract $(\mathrm{g})$ & 3 \\
3 & Sodium chloride $(\mathrm{g})$ & 5 \\
4 & Agar $(\mathrm{g})$ & 15 \\
5 & Distilled water $(\mathrm{mL})$ & 1000 \\
6 & $\mathrm{pH}$ & 7 \\
\hline
\end{tabular}

Table 2: Composition of nutrient agar medium for bacterial culture

\begin{tabular}{lll}
\hline S. No & Composition & Quantity \\
\hline 1 & Potato $(\mathrm{g})$ & 200 \\
2 & Dextrose $(\mathrm{g})$ & 20 \\
3 & Agar $(\mathrm{g})$ & 15 \\
5 & Distilled water $(\mathrm{mL})$ & 1000 \\
6 & $\mathrm{pH}$ & 6.5 \\
\hline
\end{tabular}


Table 3: Total phenolics, tannins and flavonoid content of leaf and stem extract of L.alata

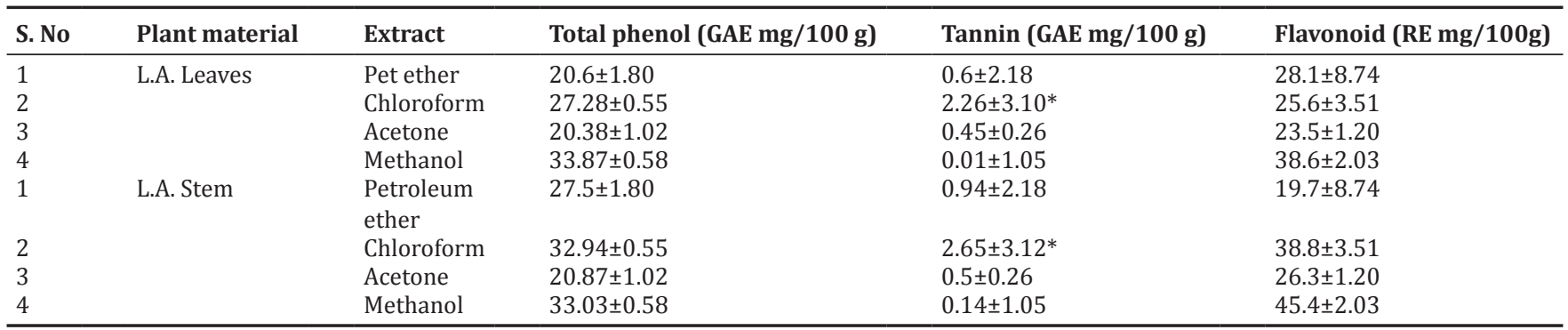

Values are mean of replicate determination ( $\mathrm{n}=3) \pm$ SD. GAE: Gallic acid equivalence, RE: Rutin equivalence, SD: Standard deviation. L. alata: Limonia alata

green phosphate/Mo(V) complex at an acid $\mathrm{pH}$. The total antioxidant capacity of different solvent extracts of leaf, stem of L. alata was analyzed and shown in Fig. 2. In L. alata leaf showed higher activity in most of its solvents compared to the extracts of the stem. The methanol extract of leaf and stem $(0.512 \mathrm{mg} / \mathrm{g} ; 0.4212 \mathrm{mg} / \mathrm{g}$ extract) has highest phosphomolybdenum reduction compared to other solvent extracts.

\section{FRAP assay}

The ferric decrease antioxidant power assay determines the antioxidant result of any substance in the reaction medium as reducing ability. Antioxidant potential of leaf and stem extract of $L$. alata were estimated from their ability to reduce TPTZ-Fe (III) complex to TPTZ- Fe (II) and the results are given in Fig. 3. L. alata methanol extract of leaf and stem methanol extract from stem extracts revealed higher activity and the values were $3214.1 \mathrm{MmolFe}(\mathrm{II}) \mathrm{E} / \mathrm{mg}$ and $11542.3 \mathrm{MmolFe}(\mathrm{II})$ $\mathrm{E} / \mathrm{mg}$ extract. The FRAP test measures the antioxidant impact of any substances in the response medium as diminishing capacity.

\section{Reducing power assay}

The presence antioxidant purpose the reduction of Fe3+/ferricyanide complex to the ferrous form. The reducing power of stem and leaf extracts of $L$. alata was calculated and the results were presented in Figs. 4 and 5. The L. alata methanol extract in stem (0.99 EDTAE/100 g) and leaf (0.68 EDTAE $/ 100 \mathrm{~g}$ ) in methanol extract shows higher reducing power compared to other extracts; the values were 9.97 EDTAE/100 g extract. The values were lower for chloroform extract.

\section{Superoxide radical $\left(\mathrm{O}_{2}{ }^{*-}\right)$ scavenging activity}

The superoxide anion radical scavenging activities of $L$. alata leaf and stem are shown in Fig. 6. The extracts were found to be an efficient scavenger of superoxide radical generated in riboflavin NBT light system in vitro. The methanol extract of L. alata leaf and stem showed higher superoxide radical scavenging activity $(332.13 \%$ and $302.15 \%)$ compared to other solvent extracts at a concentration of $100 \mu \mathrm{g} / \mathrm{mL}$. Superoxide radical is essential because it conducts as the precursor for other major ROS such as hydrogen peroxide, hydroxyl and singlet oxygen (Lee et al., 2004). The potential technique of scavenging of superoxide anion radicals in $L$. alata can be due to the effective principles in the plant extracts which may reject the superoxide anion radicals which are caused through the photo-illumination process.

\section{Metal chelating activity}

Ferrozine can quantitatively chelate with $\mathrm{Fe} 2+$ and shape a red shaded complex. This response is constrained within sight of other chelating operators and results in a diminishing of the red shade of the ferrozine-Fe2+ complex. Estimation of the shading lessening gauges the chelating movement to contend with ferrozine for the ferrous particles (Soler-Rivas et al., 2000). The antioxidants present in plant extract forms a coordinate complex with the metal ions (chelating activity) and inhibit the transfer of electrons. This oxidation reaction is arrested, and no free radicals are produced. The $\mathrm{Fe}^{+}$chelating capacity of different solvent extracts of L. alata leaf and stem are shown in Fig. 7. In L. alata maximum chelation's were observed for the methanol extract of leaf and stem (18.24 EDTAE/100g; 20.156 EDTAE/100g) extract.

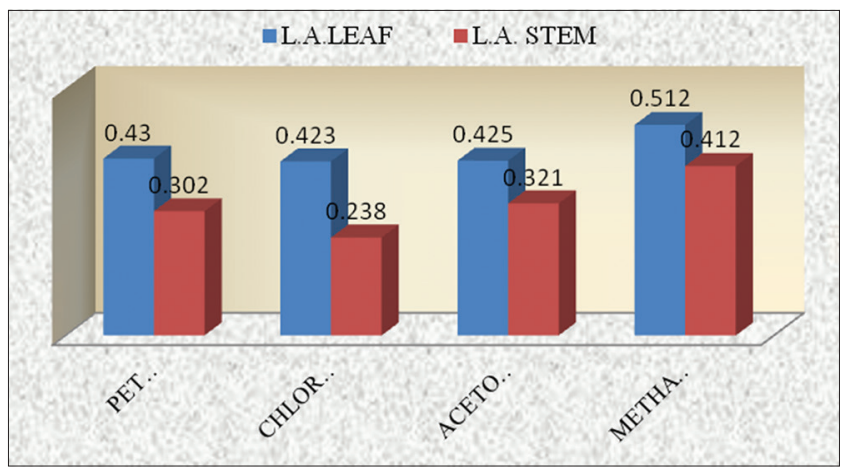

Fig. 2: Phosphomolybdenum activity of Limonia alata leaf and stem extract

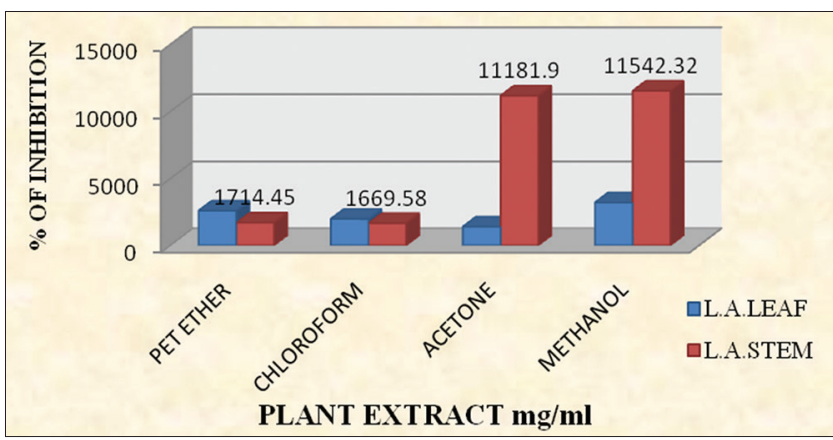

Fig. 3: Ferric reducing antioxidant power assay of Limonia alata leaf and stem extract

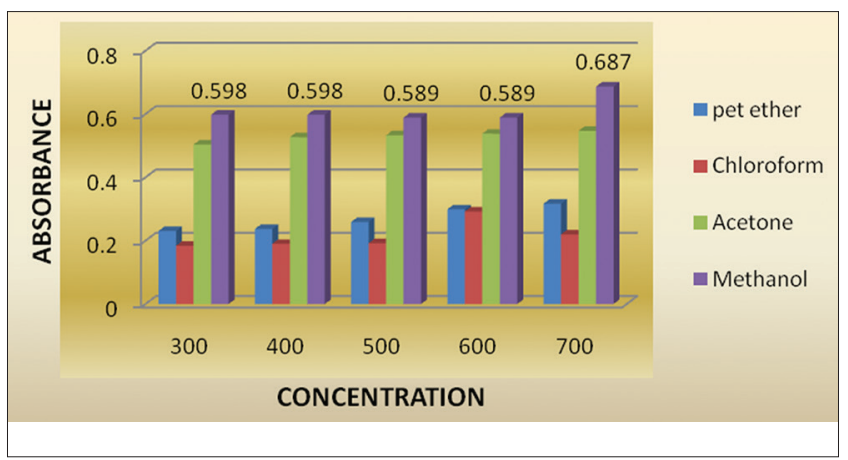

Fig. 4: Reducing power of Limonia alata leaf

\section{Antimicrobial activity}

The methanolic extract of L. alata leaf extracts was checked for their antimicrobial activity against $S$. aureus, E. coli, and C. albicans. The inhibition of microbial growth was observed. The zone of inhibition was found and measured and is presented in Table 4. The images were presented in the Plates 1-4. Among the two bacteria and two fungal zone of inhibition is higher in E. coli of $31 \mathrm{~mm}$ and in $27 \mathrm{mg} / \mathrm{mL}$ of $L$. 
Table 4: Antimicrobial activity of methanolic leaf extract of $L$. alata

\begin{tabular}{llll}
\hline Name of the pathogen & Test parameter & Zone of inhibition in $\mathbf{~ m m}$ & \\
\cline { 3 - 4 } & & Antibiotic concentration $\mathbf{( 1 0} \mathbf{~ m g} / \mathbf{m L})$ & LLM extract concentration (10 $\mathbf{~ m g} / \mathbf{m L})$ \\
\hline S. aureus & Anti-bacterial & $28 \mathrm{~mm}$ & 18 \\
E. coli & $31 \mathrm{~mm}$ & 14 \\
F. oxysporum & Anti-fungal & $14 \mathrm{~mm}$ & 21 \\
C. albicans & $27 \mathrm{~mm}$ & 12 \\
\hline
\end{tabular}

L. alata: Limonia alata, S. aureus: Streptococcus aureus, E. coli: Escherichia coli, F. oxysporum: Fusarium oxysporum, C. albicans: Candida albicans, LLM : Limonia alata leaf methanolic extract

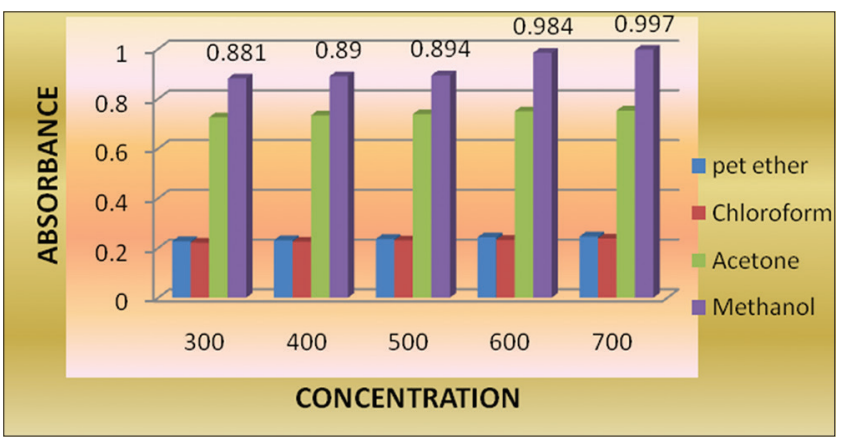

Fig. 5: Reducing power of Limonia alata stem

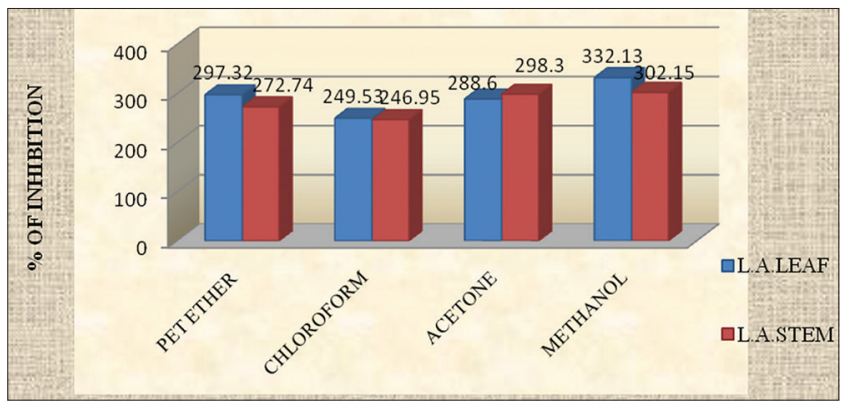

Fig. 6: Superoxide radical scavenging activity of Limonia alata leaf and stem extracts

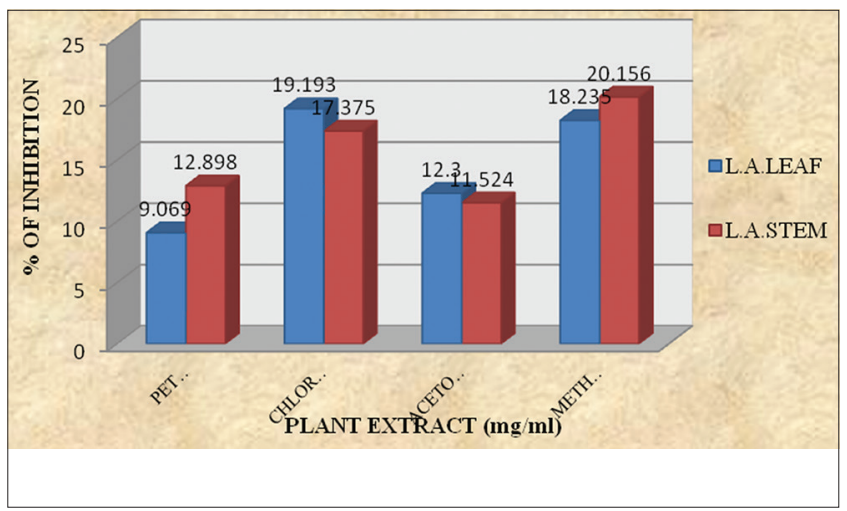

Fig. 7: Metal chelating activity of Limonia alata leaf and stem extracts

alata leaf extracts. The anti-bacterial activities are against $S$. aureus is significantly higher in E. coli. Then, fungal zone of inhibition is higher in C. albicans of $27 \mathrm{~mm}$ and $24 \mathrm{mg} / \mathrm{mL}$ of Ziziphus oenoplia leaf extracts. The anti-fungal activities are against $F$. oxysporum significantly higher in C. albicans. In case bacterial activities are against Staphylococcus S. aureus is significa of anti-fungal of the sample showed lesser activity compare to antibacterial. Hence, the plant has higher antibacterial activity it can be used as good medicine.
Antimicrobial activity of LLM extract

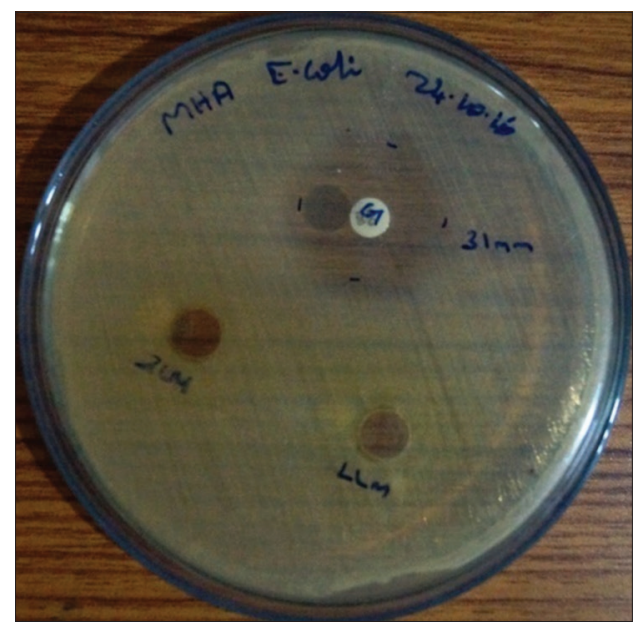

Plate 1: Escherichia coli

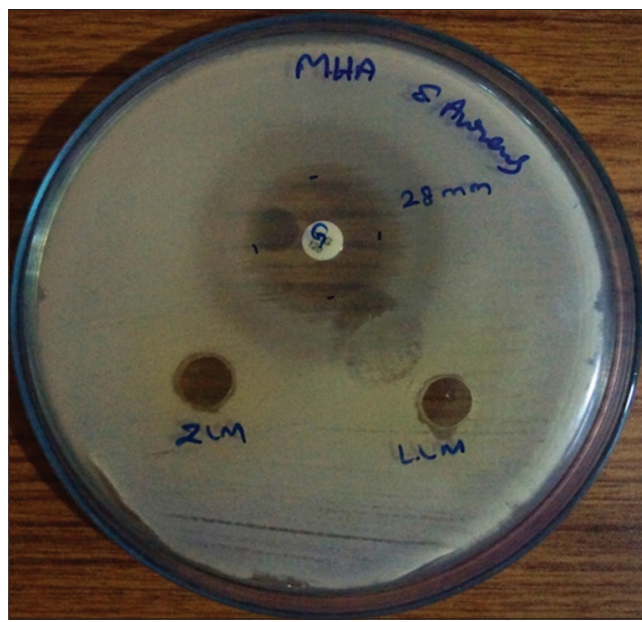

Plate 2: Streptococcus aureus

\section{CONCLUSION}

L. alata leaf can be valuable natural antioxidants, antimicrobial activity source which seemed to provide potential nutraceuticals for human health. Further, detailed exploration chemical studies and screening for medicinal properties with provide a cost effective and reliable source of medicine for the welfare of humanity.

\section{ACKNOWLEDGMENTS}

The authors are grateful to Professor and Head, Department of Botany, Bharathiar University, Coimbatore, Tamil Nadu for providing necessary facilities during the study. 


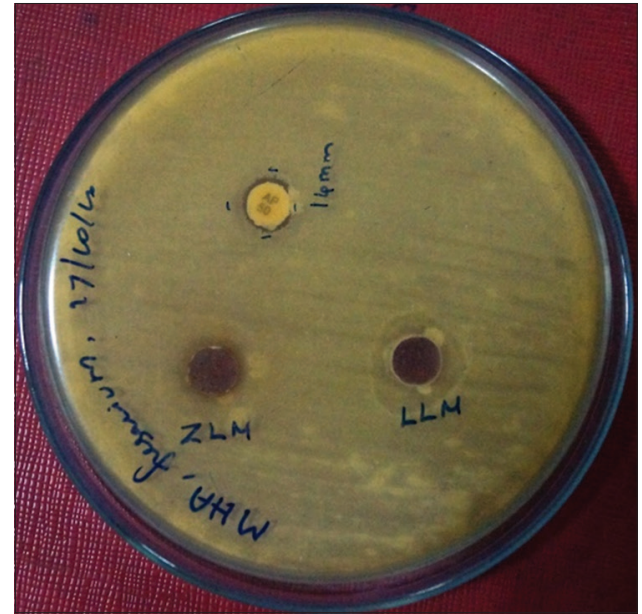

Plate 3: Fusarium oxysporum

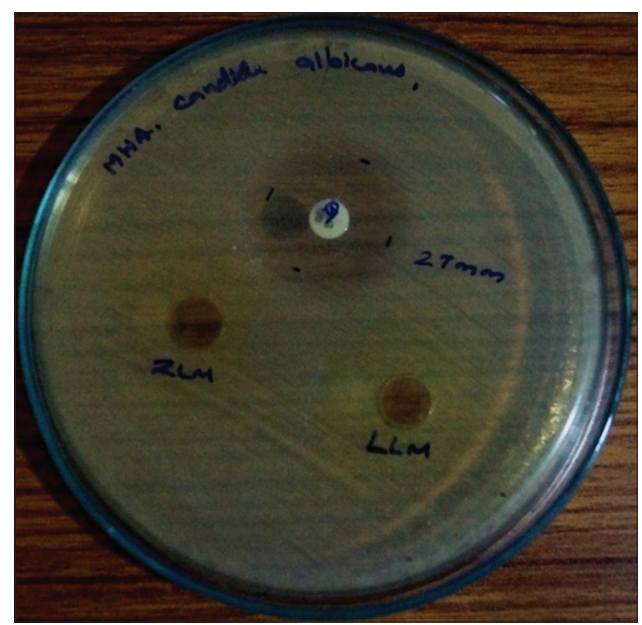

Plate 4: Candida albicans

\section{REFERENCES}

1. Azaizeh H, Fulder S, Khalil K, Said O. Ethnobotanical knowledge of local Arab practitioners in the middle eastern region. Fitoterapia 2003;74:98-108.

2. Basile A, Sorbo S, Giordano S, Ricciardi L, Ferrara S, Montesano D, et al. Antibacterial and allelopathic activity of extract from Castanea sativa leaves. Fitoterapia 2000;71:S110-6.

3. Omer ME, Elnima EI. Antimicrobial activity of Ximenia americana. Fitoterapia 2003;74:122-6.

4. Shivaprasad HN, Mohan S, Kharya MD, Shiradkar RM, Lakshman K. In vitro models for antioxidant activity evaluation: A review. Latest Rev 2005;3:4.

5. Huang DH, Chen C, Lin C, Lin Y. Antioxidant and antiproliferative activities of water spinach (Ipomoea aquatica Forsk.) constituents. Bot Bull Acad Sci 2005;46:99-106.

6. Khilfi S, Hachimi E, Khalil A, Es-Safi A, Belahyam A, Tellal A, et al. In vitro antioxidant properties of Salvia verbenaca L. Hydromethanolic extract. Indian J Pharm 2006;38:276-80.

7. Gulcin I, Alici HA, Cesur M. Determination of in-vitro antioxidant and radical scavenging activities of propofol. Pharmacol Bull 2005;53:281-5.

8. Pourmorad F, Hosseinimehr SJ, Shahabimajd N. Antioxidant activity, phenol and flavonoid contents of some selected Iranian medicinal plants. Afr J Biotechnol 2006;5:1142-5.

9. Arunkumar S, Muthuselvam M. Analysis of phytochemical constituents and antimicrobial activities of Aloe vera $\mathrm{L}$. against clinical pathogens. World J Agric Sci 2009;5:572-6.

10. Frei B. Cardiovascular disease and nutrient antioxidants: Role of lowdensity lipoprotein oxidation. Crit Rev Food Sci Nutr 1995;35:83-98.

11. Halliwell B. Free radicals and antioxidants: A personal review. Nutr Rev 1997;52:253-65.

12. Liu RH. Health benefits of fruits and vegetables are from additive and synergestic combination of phytochemicals. Am J Clin Nutr 2003;78 Suppl 3:517-20.

13. Nishaa S, Vishnupriya M, Sasikumar JM, Christabel HP, Gopalakrishnan V. Antioxidant activity of ethanolic extract of Maranta arundinacea.L Tuberous Rhizomes. Asian J Pharm Clin Res 2012;5:85-8

14. Farhan H, Rammal H, Hijazi A, Hamad H, Daher A, Reda M, et al. In vitro antioxidant activity of ethanolicand aqueous extracts from crude Malva parviflora L. grown in lebanon. Asian J Pharm Clin Res 2012;5 Suppl 3:234-8.

15. Rammal H, Bouayed J, Younos C, Soulimani R. Evidence that oxidative stress is linked to anxiety-related behaviour in mice. Brain Behav Immun 2008;22:1156-9.

16. Bunyapraphatsara N, Chokchaichareonporn A. Medicinal plants Indigenous to Thailand. Bangkok: Prachachon; 2000. p. 691.

17 Makkar HP. Quantification of Tannin in Tree and Shrub Foliage: A Laboratory Manual. Dondrecht. The Netherlands: Kluwer Academic Publishers; 2003.

18 Zhishen J, Mengecheng T, Jianming W. The determination of flavonoids contents on mulberry and their scavenging effects on superoxide radical. Food Chem 1999;64:555-9.

19 Pulido R, Bravo L, Sauro-Calixto F. Antioxident activity of dietary polyphenols as determine by a modified ferric reducing/antioxidant power assay. J Agric Food Chem 2000;48:3396-402.

20 Blios MS. Antioxidants determination by the use of a stable free radical. Nature 1958;4617:1199-200

21 Dinis TC, Madeira VM, Almeida LM. Action of phenolic derivatives (acetoaminophen, salycilate and 5-aminosalycilate) as inhibitors of membrane lipid peroxidation and as peroxyl radical scavengers. Arch Biochem Biophys 1994;315:161-9.

22 Beauchamp C, Fridovich I. Superoxide dismutase: Improved assay applicable to acrylaminde gels. Anal Biochem 1971;44:276-7.

23 Mojab F, Kamalinejad M, Ghaderi N, Vahidipour H. Phytochemical screening of some Iranian plants. Iran J Pharm Res 2003;3:77-82. 23.

24 Bamforth CW, Muller RE, Walker MD. Oxygen and oxygen radicals in malting and brewing: A review. J Am Soc Brew Chem 1993;53:79-88.

25 Blios MS. Antioxidant determinations by the use of a stable freeradical Nature 1958;26:1199-200.

26 Chung KT, Wong TY, Huang YW, Lin Y. Tannins and human health: A review. Crit Rev Food Sci Nutr 1998;38:421-64.

27 Hippeli S, Elstner EF. Transition metal ion-catalyzed oxygen activation during pathogenic processes. FEBS Lett 1999;443:1-7.

28 Jadhav SJ, Nimbalkar SS, Kulkarni AD, Madhavi DL. Lipid oxidation in biological and food systems. In: Madhavi DL, Deshpande SS, Salunkhe DK, editors. Food Antioxidants. New York: Dekker Press; 1996. p. 5-63.

29 Klein SM, Cohen G, Cederbaum AI. Production of formaldehyde during metabolism of dimethyl sulphoxide by hydroxyl radical generating system. Biochemistry 1991;20:6006-12.

30 Kulisic T, Radonic A, Katalinic V, Milos M. Use of different methods for testing antioxidative activity of oregano essential oil. Food Chem 2004;85:633-40

31 Liu H, Qiu N, Ding H, Yao R. Polyphenols contents and antioxidant capacity of 68 Chinese herbals suitable for medical or food uses. Food Res Intern 2008;41:363-70.

32 Loo AY, Jain K, Darah I. Antioxidant activity of compounds isolated from the pyroligneous acid, Rhizophora apiculata. Food Chem 2008;107:1151-60.

33. Lu YR, Foo LY. Antioxidant activities of polyphenols from sage (Salvia officinalis). Food Chem 2001;75:197-202. 